\title{
THE SCHOOLING OF SCIENCE TEACHING IN PRIMARY EDUCATION IN PARANÁ: BETWEEN DISENCHANTMENT OF THE WORLD AND UTILITARIANISM, NUANCES OF A MORAL EDUCATION
}

\author{
Sidmar dos Santos Meurer ${ }^{*}$
}

\begin{abstract}
This text analyzes the schooling process as to what was called "scientific teaching" in primary education in the state of Paraná (Brazil), over the first three decades of the XX century. From the perspective of the curriculum history, it analyzes interactions between arguments in favor of its introduction and the emergence of the subject Physical and Natural Sciences in the study programs. As sources, it mobilizes educational reform projects, the pedagogical press, as well as normative documents, official reports and teaching programs. The analysis allows identifying two moments in the path of the respective school subject. The first, as of the first decade of the $\mathrm{XX}$ century, when the array of the contents to be taught receives less attention than the assimilation of a mental and behavioral discipline. The second, around the 1920s, when the utility of the contents in relation to labor and hygiene habits is highlighted.
\end{abstract}

Keywords: science teaching, curriculum history, educational reforms, history of sensitivities.

* Universidade Federal do Paraná (UFPR), Curitiba/PR, Brasil. 


\title{
A ESCOLARIZAÇÃO DO ENSINO DE CIÊNCIAS NA EDUCAÇÃO PRIMÁRIA NO PARANÁ: ENTRE O DESENCANTAMENTO DO MUNDO E O UTILITARISMO, MATIZES DE EDUCAÇÃO MORAL
}

\begin{abstract}
RESUMO
O texto analisa o processo de escolarização do que se denominou "ensino científico" na educação primária no Estado do Paraná (Brasil), ao longo das três primeiras décadas do século XX. A partir da ótica da história do currículo, analisa as interações entre enunciados a favor da sua introdução e o aparecimento da rubrica Sciencias Physicas e Naturaes no programa de estudos. Como fontes, mobiliza projetos de reforma do ensino, a imprensa pedagógica, além de documentos normativos, relatórios oficiais e programas de ensino. A análise permite identificar dois momentos na trajetória da respectiva matéria escolar. $\mathrm{O}$ primeiro, a partir da primeira década do século XX, quando o elenco dos conteúdos a serem ensinados ganham menos atenção do que a assimilação de uma disciplina mental e comportamental. O segundo, por volta da década de 1920, quando se destaca a utilidade dos conteúdos em relação com os costumes laborais e higiênicos.
\end{abstract}

Palavras-chave: ensino de ciências, história do currículo, reformas educacionais, história das sensibilidades.

\section{LA ESCOLARIZACIÓN DE LA ENSEÑANZA DE CIENCIAS EN LA EDUCACIÓN PRIMARIA EN PARANÁ: ENTRE EL DESENCATAMIENTO DEL MUNDO Y EL UTILITARISMO, MATICES DE EDUCACIÓN MORAL}

\section{RESUMEN}

El texto trata del proceso de escolarización de lo que se denominó "enseñanza científica" en la educación primaria en el Estado de Paraná (Brasil), a lo largo de las tres primeras décadas del siglo XX. A partir de la óptica de la historia del currículo, analiza las interacciones entre enunciados a favor de su introducción y el aparecimiento de la rúbrica Sciencias Physicas $e$ Naturaes en el programa de estudios. Como fuentes, moviliza proyectos de reforma de la enseñanza, prensa pedagógica, además de documentos normativos, informes oficiales y programas de enseñanza. El análisis permite identificar dos momentos en la trayectoria de la respectiva materia escolar. El primero, a partir de la primera década del siglo XX, cuando los contenidos a ser enseñados ganan menos atención que la asimilación de una disciplina mental y comportamental. El segundo, alrededor de la década de 1920, cuando se destaca la utilidad de los contenidos en relación con las costumbres laborales e higiénicas.

Palabras clave: enseñanza de las ciencias, historia del currículo, reformas educativas, historia de las sensibilidades. 


\section{LA SCOLARISATION DE L'ENSEIGNEMENT DES SCIENCES DANS L'ENSEIGNEMENT PRIMAIRE DANS L'ÉTAT DU PARANA: ENTRE LE DÉSENCHANTEMENT DU MONDE ET L' UTILITARISME, NUANCES DE L'ÉDUCATION MORALE}

\section{RESUME}

Le texte traite du processus de scolarisation de ce qu'on a appelé "l'enseignement scientifique" dans l'enseignement primaire dans l'état du Parana (Brésil), au cours des trois premières décennies du XXe siècle. Du point de vue de l'histoire du curriculum, il analyse les intéractions entre les énoncés en faveur de son introduction et l'apparition de la rubrique Sciences Physiques et Naturelles au programme scolaire. En tant que ressources, il mobilise des projets de réforme de l'éducation, la presse pédagogique, en plus de documents normatifs, de rapports officiels et des programmes d'enseignement. L'analyse permet d'identifier deux moments dans la trajectoire de cette matière scolaire. Le premier, à partir de la première décennie du XXe siècle, lorsque la liste des contenus à enseigner attire moins l'attention que son rôle dans l'assimilation d'une discipline mentale et comportamentale. Le second, autour des années 1920, lorsque l'utilité du contenu par rapport aux coutumes du travail et de l'hygiène a été mise en évidence.

Mots-clés: enseignement des sciences; histoire du curriculum; réformes éducatives; histoire des sensibilités. 


\section{INTRODUCTION}

The processes of emergence and stabilization of subjects in school curricula are privileged areas for deepening the historical understanding of the ambience and character of the relations that a society establishes with its school systems, as well as the educational expectations that are projected on a cultural component over time (GOODSON, 1995). Based on this premise, this text addresses the process that I call the schooling of science teaching, marked by its emergence and affirmation as a subject in the programs for primary schools in the state of Paraná (Brazil), in a trajectory that covers the first three decades of the XX century.

The defense of the inclusion of science teaching arises from a set of expectations around reforming the primary school in Paraná that had been advancing since the end of the XIX century. Expectations which discussed its organization and mode of operation; socio-cultural senses and priorities; composition, scope and breadth of knowledge to be disseminated by the primary school. The tensions related to the design of teaching programs were a place to which many of these expectations flowed. As a result of this ambience, we saw, concerning Paranás context in the early years of the XX century, an intricate picture of projects and initiatives aimed at reforming the school that bet heavily on the possibility of transforming it through changes in programs. Notwithstanding its own dynamics as to the theme of schooling reform in Paraná, marked by the repeal of two reforms immediately after being implemented, it was within this movement that the subject Physical and Natural Sciences was instituted in the official program for primary schools in the state.

The text questions this appearance until the moment of its stabilization or affirmation. From the perspective of curriculum history, it analyzes arguments in favor of the introduction and permanence of this subject in primary schooling in the state, as well as the way that objectives, contents, 
forms, methods and teaching materials were prescribed in order to capture expectations around the contribution of scientific knowledge to elementary education. The aim is to capture important indicators as to how selections of values and socio-cultural purposes were operated.

Therefore, as an expository strategy, the text emphasizes two moments along this path. First, the arguments that advocated for its introduction and that are related to the appearance of the subject in the teaching program, as of the beginning of the XX century until the mid-1910s. And then, what I consider to be an inflection movement in the senses connected to its permanence in the program, which goes through legitimating objectives and discourses, from the final years of the 1910s, and which becomes clearer in the 1920s. As sources, a set of propositions aimed at the primary school put into circulation in the pedagogical press was mobilized, as well as projects and other publications related to attempts at reforming teaching, in addition to normative documents, official reports and teaching programs. The analysis of the material suggests a series of nuances related to the introduction of science teaching in the program for primary schools, deriving from divergences as to the purposes that were designed for this educational institution.

\section{AT WHAT PURPOSES THE ARGUMENTS IN FAVOR OF INCLUDING SCIENCE TEACHING IN THE PROGRAM FOR PRIMARY SCHOOLS IN PARANÁ ARE AIMED?}

When Victor Ferreira do Amaral, then Director General of Public Instruction of the state, sought to rationally and gradually organize the program established in the regulation in force ${ }^{1}$, he resented not being able to include,

\footnotetext{
${ }^{1}$ Regulation on Public Instruction of the State of Paraná, put into effect by the state presidency through Decree No 93, of March 11, 1901. Although attempts at reforming public instruction still in the 1900s succeeded in revoking it twice, both times it is quickly reactivated on the grounds of restoration or restart, remaining in force until the mid-1910s.
} 
among the set of subjects for primary schools, some general notions of natural, physical and chemical history, since there was no legal provision for teaching such subject and/or content. Nevertheless, he considered this knowledge indispensable to popular education and, as soon as the law allowed, it should be included in the respective programs (apud SILVA, 1904).

This demand mobilized a whole set of statements and arguments that had been formed around the problem of elementary education in the debate on educational renewal in the state. Argumentation which was accommodated around the assumptions of Herbert Spencer, the main common reference among those engaged in debating public instruction. Said assumptions served as a basis to promote some structuring positions in the educational debate, among which the following stand out: that the problem of education of the population concerned the possibility of equalizing the diffusion of the initial levels of teaching through the different social classes, and the breadth of the education provided; that education presupposed a human activity of greater scope than mere instruction, that is, it implied a training that reached one's physical, moral and intellectual dimensions (and, for some, aesthetics); and that education should be carried out on rational bases, attuned to the demands and the spirit of the present time, that is, on scientific and positive grounds.

Science had become the expression of a superior rationality, which was intrinsically linked to the result of the progress of human existence. In addition, the science-based teaching proposed by Spencer was the main component to feed the imperative of pedagogical renewal. The association between utility value and science produced tension in relation to the content of schooling from words to things. This sort of intellectual fund is one of the points that supported the defense of scientific teaching in primary school, the schooling stage that was associated with popular education, as the foundation for the realization of a discipline of the spirit (at the same time intellectual, moral, behavioral and aesthetic).

Dario Vellozo, one of the main voices in the debate on educational 
reform in the state throughout the $1900 \mathbf{s}^{2}$, was an advocate of scientific teaching for popular education, not exactly as a school subject, but as a discipline for the development of reason. In the first of a sequence of articles published in the journal $A$ Escola 3 , he chose a passage by the French author Edmond Scherer as the epigraph and illustration of his argumentation.

Science, in fact, does not consist only of a sum of knowledge that is necessary to possess; Science is, above all, the scientific spirit, it is investigation, it is the why and how raised at each step, it is the suspicion of ideas received, it is faith in reason, it is vigor as to proofs, it is the sovereign evidence of certainty (apud VELLOZO, 1907, p. 1).

It was the pursuit of this understanding of education in the spirit of science that prevailed in the incorporation of the subject Physical and Natural Sciences in the programs prescribed both in 1907 and 19094, the first

${ }^{2}$ One of the most prominent names in the pedagogical renewal movement in the state (Cf. VIEIRA, 2001), linked to the symbolist literary movement in Paraná, Dario Vellozo collaborated in the publishing of several journals, acting as a writer and editor in some of the most important literary publications of the city of Curitiba. Linked to masonry, he was given the title of Grand Master of the Luz Invisível Lodge in Curitiba, and was Delegate of the Grande Oriente do Brasil, in Paraná. One of the main leaders of the anticlerical movement in Paraná, he dedicated a large portion of his editorial work to the topic. He was one of the founders of the Historical and Geographic Institute of Paraná and founded, in the early 1910s, the Neo-Pythagorean Institute, an association of free thinkers that brought together other intellectuals in celebration of the Hellenic culture and for the fight against clericalism. A teacher at Ginásio Paranaense and Escola Normal do Estado, he occupied the Pedagogy and General History of Civilization chairs. In 1907, he published the work "Pedagogy Compendium" [Compendio de Pedagogia], a publication in which he compiled his considerations on modern pedagogy, which, for some years, was the main theoretical reference for teacher training in Paraná. He had an active participation in conceiving the Public Instruction Reform of 1907 and made important contributions to the text of the Regulation that resulted from said reform. He was the author of the bill that, after being discussed in the State Assembly, culminated in the education reform and in the Organic Regulation on Public Instruction of 1909.

3 Publication by the Guild of Public Teachers of the State of Paraná that circulated between 1906 and 1911, aimed at spreading pedagogical ideas for Paraná's body of teachers. Between 1907 and 1908, it was funded by the state government. Dario Vellozo worked as editor between 1906 and 1909. While in charge of the journal's editorial staff, he published a series of articles of his own, as well as transcripts of articles featured in various newspapers in the country and the translation of articles by international authors who, in some way, related to the precepts he defended.

4 Through Decree No. 479 of December 10, 1907, the state presidency sanctioned a new Public Instruction Regulation - as a result of Law 723 (which authorized the reform) of April 2 of the 
appearances of the subject in the official program for primary school. The 1907 regulation included a specific article on its ideal didactic treatment.

Art. 63. Teachers shall strive to organize small museums of collections or isolated objects that awaken in their students a taste for the study of physical and natural sciences, about which they will lecture, giving them the elementary notions of this knowledge (PARANÁ, 1907, p. 8).

There is much that is synthesized in this prescription. Firstly, the indication that the teaching of the subject should focus on its elementary notions. Besides, the confirmation that the teaching of this knowledge had as expectation the formation of a set of attitudes and procedures on the part of the students. In the passage in question, this expectation found the somewhat unpretentious form of expression "awakening a taste". And finally, the suggestion of a way to teach this knowledge based on the use of objects, also encouraging the formation of museums and collections in schools. We thus have what can be characterized as a curricular complex, inasmuch as the prescription indicates a body of teaching content, a way of doing it and a set of purposes (SACRISTÁN, 2004).

Another article published in the journal A Escola, deriving from the editorial work of Dario Vellozo, offers an inventory of clues about how this complex had been formed. It is Vellozo's translation of a work attributed to Alicia Moreau 5 and entitled Pedagogy and The School [A pedagogia e a escola]. Vellozo presented the text highlighting that it had circulated in the Argentinian press, and that he considered its content worthy of "study and meditation on the

\footnotetext{
same year -, which was to take effect as of January 16, 1908, beginning of the school year. However, soon on February 19, 1908, the Legislative Assembly passed another law suspending the execution of the new regulation. In a new decree of October 5, 1909, the state presidency put into immediate effect the Organic Regulation on Public Instruction of the state, which stemmed from Law 810 (Reorganization of Public Instruction), of April 19, 1909. Once again, the Legislative Assembly passed a law (No. 944), on April 4, 1910, suspending the execution of the new regulation and commanding the resumption of the execution of the 1901 Regulation.

5 Although D. Vellozo is not concerned with introducing the author to readers, it is probably Alicia Moreau de Justo.
} 
part of those interested in teaching".

The text is structured in the defense of the following maxim:

The group of scientific knowledge, especially of natural sciences, must form the basis of the entire plan of primary, secondary and moral studies. [...] those who want a better future for man, those who dream of a different society, if they were practical and not poets, would turn their eyes to education (MOREAU, 1906, p. 155).

According to the argumentation, teaching should serve a dual purpose: "to educate the individual by disciplining their spirit", which would allow their mental development; and to provide that "sum of knowledge" necessary in their relationship with the environment and with "their peers", equipping them to act in society. The author recognized that education was the acquisition of a set of knowledge, but it was also something that lasts in the individual beyond that knowledge and even the time during which they are in relationship with it. Science teaching should compose the most appropriate set of teachings for the achievement of these purposes, because it consisted of an "excellent instrument of culture" in its dual aspect: that of "intellectual creation" and that of production of a common way of life (idem, p. 156).

These considerations were anchored in a set of assumptions in relation to the path of human intellectual development, the process of which was directed from "contact with the external world" to the formation of the mind. The first element involved in this mediation would be sensation, described as the "reaction of the organism against the environment, the transformation of energy into our nervous substance", through the mobilization of the senses. This was a principle of the functioning of the psyche in childhood, and any educational initiative that strayed from this path represented violence against the nature of childhood life, producing, as a consequence, anti-educational effects. Moreover, from the cultivation of the faculty of observation all the other faculties necessary for the human spirit would derive: "imagination", "critical 
sense", "feeling of value", from where the "affective and moral life" would emerge (idem, p. 158). Aspects stressed by Dario Vellozo in his writings regarding educational purposes.

A teaching capable of promoting the cultivation of observation was, therefore, that which was anchored in things or objects and in the ordered and directed exercise of the physical senses in contact with them. This was not necessarily the property of a subject. It could be done through the intuitive teaching of a variety of subjects or through lessons of things. The result is that all of these themes were scrambled, and the allusion to the physical and natural sciences at that time mobilized this entire thematic complex. Therefore, we can state that the appearance of the subject Physical and Natural Sciences in the context of primary schooling in Paraná is implicated in the common fund associated with the pedagogical renewal movement underway in western countries since the end of the XIX century (VALDEMARIN, 2004; MUNAKATA, 2012). The important thing is to try to capture the implications that this fund produced in each context.

With regard to the implications or consequences of the mobilization of this thematic complex, there is another aspect to highlight when it comes to the characterization of "scientific teaching" as a discipline of the spirit: its place as the basis of a moral education that should rise from individual reason and not from the authority of another individual or institution. The teaching of natural sciences, as it was able to make the child establish a contact with nature, could make them love, thus providing a "moral lesson more powerful than the tales imagined by the authors of practical-moral manuals" (MOREAU, 1906, p. 160). Furthermore, it would provide a powerful basis capable of enabling in each individual the beam of conscience able to sustain the flourishing of reason and thus enhance their capacity for social action. Especially in Dario Vellozo, the cultivation of this discipline in a scientific spirit was an indispensable element for updating the classic Enlightenment assumptions of unity, universality and natural equality among men, from where the just and necessary inequalities 
could arise, fruit of different capacities and individual wills.

Teaching in a scientific spirit was thus linked to the possibility of founding a positive morality, that is, one which was affirmed not by duress or coercion (through the introjection of the feeling of fear, guilt or remorse, for instance), but as a result of cultivation of individual qualities of judgment and ennoblement of the will (VELLOZO, 1909). This bet on a scientific morality was aimed at overcoming what was understood as a dogmatic morality of a religious nature. Its main target was the Catholic educational tradition, especially for the way it instilled a morality that deformed and stifled individual conscience and will.

Through a teaching that, in contact with nature, would allow man to recognize himself inscribed in it, he could untangle himself from the forces and ideas that imprisoned men. To achieve this purpose, the role of knowledge was less important than a series of attitudes and procedures to be awakened in order to cultivate a sense of observation. A science-based education would be expressed more by "educational results" than by the amount of knowledge that could be taught. For it was perfectly known "that the knowledge acquired at this age is not very long-lasting, that it is necessary to renew it frequently". However, even if knowledge itself faded, something would remain. In an effort to try to name this something that would remain, Moreau's text suggested: "what is not lost is the orientation, the discipline, the functional modality, if so can be said, that the learning of these sciences can give" (1906, p. 159).

Would this "educational result" not be a sensitivity, in the sense of what Braghini, Munakata and Taborda de Oliveira $(2017$, p. 7 ; 46) characterize as "subjectivation processes that emerge from the experience with the world of the objects", in terms of patterns or more or less shared bundles of responses that "individuals produce to stimuli resulting from their relationship with the physical and/or social world through the physical senses"? It is significant that the author describes this result in terms of a "form", which the sensations helped shape, but which at the same time directs a child's perceptual 
mechanisms in the organization of the following sensations. A "form" to which "subsequent studies" could add "content" (MOREAU, 1906, p. 159).

\section{INFLECTIONS AND DISPLACEMENTS DUE TO THE FIXATION OF SCIENCE TEACHING IN THE PROGRAMS FOR PRIMARY SCHOOLS IN PARANÁ.}

Another bundle of meanings and purposes for the teaching of science joined the idea of producing a mental discipline or sensitivity in the late 1900s, and since then it has gained prominence in the way that this knowledge started to appear in teaching programs. Mainly close to the 1920s, when the prospect of promoting a practical or scientific moral education started to be opposed in the name of an education of moral restoration, which should be anchored in the recovery of the values of the Catholic faith tradition (God), of the duties towards the uplift of the nation (Homeland), and of the family as a place of cultivation of social life ${ }^{6}$. This understanding was close to a more utilitarian perspective, in the sense that it shifted all the emphasis to the practical utility of knowledge in terms of the possibility of application to life or to daily occupations.

The first most visible sign in this regard was in the reform law and in the 1909 Organic Regulation, which prescribed that the "rudimentary notions of physics, chemistry and natural history" composed a subject, whose knowledge should be "sufficient for their applications to the main rudiments of hygiene and agronomy" (PARANÁ, 1909, p. 9). Both hygiene and agronomy had a major place in relation to the proposition of educational purposes for the primary school in those years, as indispensable knowledge to promote a project of social modernization in the state.

\footnotetext{
${ }^{6}$ The argumentation around the God, Homeland and family triad as the core of the moral and civic education to be promoted by public education in Paraná, can be apprehended in the official documentation of the public education service prepared mainly in the first half of the 1920 (e.g., MARTINEZ, 1920; 1921; 1922 and 1923). Other aspects can be found in the works by MORENO (2007) and CAMPOS (2007), which highlight the arrival of the political group linked to Catholicism to the state government.
} 
Francisco de Azevedo Macedo, who, while in the general direction of public education, led the education reform in the mid-1910s, which culminated in the enactment of a new Teaching Code in $1915^{7}$, paved a large way to the sense of education in a scientific spirit by prioritizing the procedural dimension in a program he organized in 1914 - which pursued, in a somewhat diffuse manner, the assumption of lesson of things or through things. In the amalgamation that this program represented, the utilitarian sense was already visible covering the inclusion of scientific teaching lessons ${ }^{8}$. At the end of that year, he indicated, among the set of "innovations" that had been introduced in Paranás schools through the new program, the "notions of Physics, Chemistry and Natural History, with useful applications to the arts and crafts, and especially to agriculture and hygiene" (Macedo, 1914 apud SANTOS, 1915).

This utilitarian perspective became even more pronounced in the prescriptions that followed. Beginning with the $1917^{9}$ Program for the Model School Group and Similar Ones, the purposes listed for the teaching of sciences are almost all marked by the appeal of its utility for the realization of daily life and work. The result of the definitions present in that program presents a kind

\footnotetext{
7 Enacted through the Decree (No 710 of October 18,1915$)$ by the state presidency, and set forth in the Education Reform Law (No 1236, of May 2, 1912).

8 The 1912 Education Reform Law included, concerning the teaching of sciences in primary schools: "Rudimentary notions of astronomy, physics, chemistry and natural history"; "rudimentary notions of biology, sociology and morality"; and "practical notions of agronomy" (PARANÁ, 1912, p. 143). In the program that Azevedo Macedo offered to schools in 1914, this course gained the following configuration: for the 1st Grade: "1. Varied and interesting lectures by the teacher to their students: a) to educate their senses; b) to form the habit of understanding and observing well [..]; 2. Study of the shapes of things, their similarities and differences [...]. 6. Notions of the size of things; 7. Notions of the quality of things. 8. Notions of time and its measurement. 9. Notions of the sound". For the 2nd Grade: "[...] 3. Lessons of things". For the 3rd Grade: "[...] 5. Progressive sequence of the lessons of things. 6. Study of the human body. [...] 13. Rudimentary notions of Physics, Chemistry and Natural History, with useful applications to the arts and crafts and, especially, to agriculture and hygiene". And for the 4th Grade: "[...] 12. Recap and expansion of the applied notions of Physics, Chemistry and Natural History. 13. Fundamental notions and practices of Agronomy. 14. Fundamental notions and practices of Hygiene" (PARANÁ, 1914, pp 5 - 8).

9 The respective program followed the enactment of the Teaching Code (Decree No 17 of January 9, 1917). This new regulatory text introduced a few adjustments and updates to the 1915 text, such as the creation of Model School Groups, with a specific program. This program condensed again scientific education in the form of the subject "Physical and Natural Sciences".
} 
of combination between the two senses that were being built over those years, in a way that 'observation' and 'utility' are taken as the foundations of realization for all points contained in the program. The set formed the aspect of synthesis between that meaning that evoked the more procedural dimension on the array of knowledge, and the dimension that valued its applicability.

For instance, the program for the $1^{\text {st }}$ year listed the following points:

\author{
$1^{\text {st }}$ Oral language about chickens, cows and fish; \\ $2^{\text {nd }}$ Oral language about a known plant; \\ $3^{\text {rd }}$ Oral language about some stones; \\ $4^{\text {th }}$ Distinction between the kingdoms of nature; \\ $5^{\text {th }}$ Summarized notions about the 3 states of the bodies; \\ $6^{\text {th }}$ Idem for the parts of the human body, in natural terms; \\ $7^{\text {th }}$ Idem for plant parts (PARANÁ, 1917, p. 43).
}

Along with the indication of the subjects to be taught, the program was completed by the prescription of a didactic structure for its development, which was based on these two aspects: that of utility and that of observation.
a) - making students observe;
b) - saying, in order, what they have observed;
c) - utility for man and why;
d) - considerations on the topic of the point (ibidem).

This prescription formalized the steps that should be taken to carry out the intuitive method - observation, classification, elaboration, abstraction (VALDEMARIN, 2004). However, as for the characterization of the purposes of this subject, the evocation of the experimental sense of teaching was not above the utility value of the contents taught, a value which would be deduced from the possibility of applying that knowledge. As can be seen, for instance, from the 
prescription of the following point, included in the array of contents for the $3^{\text {rd }}$ year:

On leaves, flowers, fruits and seeds, the following will be covered:

a) - observation of a branch with leaves and flowers, and another with leaves and fruits; flowers, leaves and fruits of various species;

b) - telling how the leaves are attached to the branch;

c) - shapes, colors and utility for man - hygienic and dietary measure of leaves;

d) - shapes, colors and utility of flowers; their consequence - the fruit;

e) - shapes, colors and utility of fruits (PARANÁ, 1917, p. 45).

At the beginning of the 1920s, the teaching of scientific content took on an even more utilitarian sense. When curriculum definitions split the primaryschooling system of the state into a program for isolated schools and another one for school groups, the principle of utility was mobilized in the definition of the array of knowledge capable of adapting the teaching of this subject to the environment where the school was inserted. This aspect was even more striking for the program proposed for isolated schools. For said schools, which, through curriculum definitions, were associated with the rural environment, the proposed program indicated the following set of topics to be taught.

Chart 1 - Program for the Study of Physical and Natural Sciences in the Program for Isolated Schools of the State in 1920.

\begin{tabular}{|l|l|}
\hline & a) Explain what a metal is and give an example of the most useful metals. \\
& b) Solid, liquid and gaseous bodies. \\
& c) Water: fresh or drinking, brackish, saline, medicinal water, etc. \\
d) Hygiene of the body and clothing. Hand cleaning, mouth, ear, eye care, & etc. \\
$\mathbf{1}^{\text {st }}$ Year & e) Malaria and ancylostomiasis. Means to prevent and cure these \\
diseases. & f) Smallpox and the need for vaccine. \\
g) Parts of a vegetable. Utility of plants. Need for planting to have \\
abundance. What should be planted in the backyards. Fruits, cassava, \\
beans, rice, corn. \\
h) Raising of pigs, chickens, kids, sheep, etc.
\end{tabular}




\begin{tabular}{|c|c|}
\hline & $\begin{array}{l}\text { i) Experiences with planting in a plot adjacent to the school, at convenient } \\
\text { times, with the teacher giving examples of the work. }\end{array}$ \\
\hline $2^{\text {nd }}$ Year & $\begin{array}{l}\text { a) Recap of the } 1^{\text {st-year program. }} \\
\text { b) Beekeeping. Importance and utility of honey and wax. } \\
\text { c) Wheat and its growing. } \\
\text { d) The making of bread. } \\
\text { e) Utility of birds and the protection they deserve. } \\
\text { f) Deforestation. The danger of forests and, therefore, of this irreplaceable } \\
\text { treasure, disappearing. Need to plant essential forests. The } \\
\text { importance that comes from reforestation. } \\
\text { g) The planting of flax and its utility. } \\
\text { h) The planting of cotton and its use. } \\
\text { i) Sugarcane. The making of sugar. }\end{array}$ \\
\hline $3^{\text {rd }}$ Year & 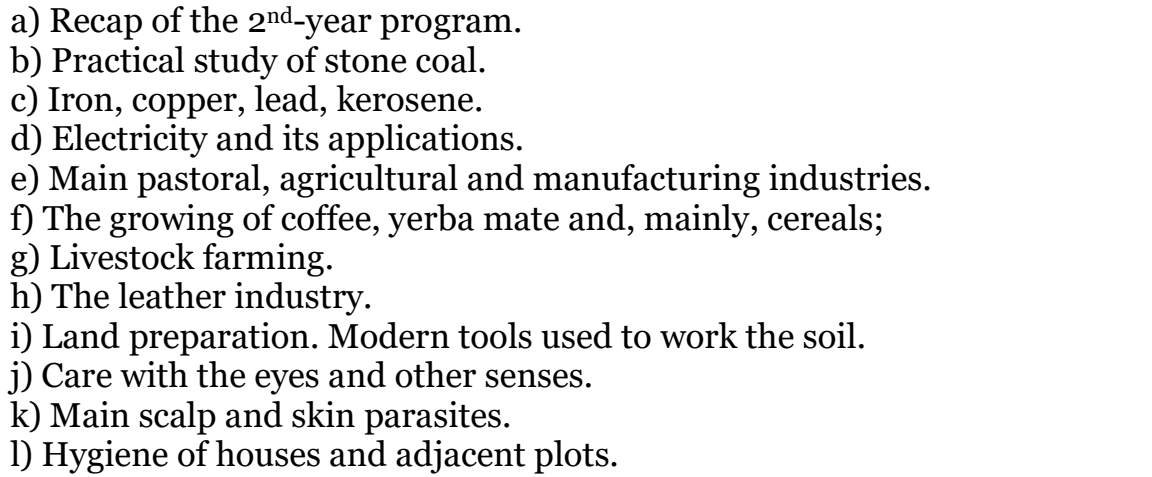 \\
\hline
\end{tabular}

Source: PARANÁ (1920, n.p.).

Analyzing the themes that should be taught throughout the course, it is perceptible that the notion of utility, in the sense of knowledge that could have a "practical application", had been established as the main selection criterion with a view to adapting the set of knowledge to be taught to the purposes assigned to the subject. A sense of goal-oriented activities, taken from an idealized social reality, seems to fly over the composition of the program. Among these goaloriented activities, knowledge that was related to the possibility of application to agricultural activities and to the creation of hygiene habits predominated. In addition, the realization of the subject was part of a sense of moral formation, in which the habit of regular and productive work was a desired value. This aspect is further reinforced by the indication that accompanied the proposed study program, that the subject was intended to "awaken the love for industries and enable the student to know the diseases and the means to cure them" (PARANÁ, 1920, p. 38). 
That indication that prevailed in the first decade of the XIX century, of scientific teaching as cultivation of the qualities capable of producing the spirit of scientific investigation as a discipline, in which the educational results deriving from the procedural components (training of observation and of the judgment sense) would be more important than the value of knowledge itself, now seems very distant. The appeal to the procedural dimension of the subject was moved to an accessory place: an efficient means for carrying out teaching, close to the sense of method. Among the set of guidelines for the execution of the respective program, the prescription indicated that, aiming at the convenience of organizing the teacher's work, physical and natural science classes could be "taught together, to all classes". In addition, it suggested that the most convenient way to teach this knowledge was through "lectures with students": "These classes do not require much effort from children and are, for this reason, called recreational classes" (idem, p. 30).

The prescription suspended, even if temporarily, the principle of serialization that was pointed out as the main axis of the reform ${ }^{10}$. It was a legal recognition that, under certain circumstances, the principle of teaching grading could be sacrificed for the convenience of the teacher's work. What circumstances? Those associated with the teaching of subjects of lesser importance or 'more recreational' ones. These prescriptions suggest a curricular configuration in which the degree of importance of science teaching is very different from the teaching of knowledge such as reading, writing and counting, for which the definitions reiterate a very rigid grading structure, with no flexibilization prerogatives. On the other hand, it is also a place of much less importance compared to the cogitations of the beginning of the century around the realization of a type of teaching that took scientific knowledge as the basis of all education. It is, in short, a place of less importance that caused, in many

\footnotetext{
10 In his annual reports, Macedo reiterated the centrality of serialization in promoting the "pedagogical reform" in the state. In the report at the end of 1913, he stated: "The content of the program is inseparable from the serialization of teaching. The serialization of teaching is the application of the economic laws of the division of labor and of the best result with the least effort" (apud SANTOS, 1914, p. 12).
} 
schools, the teaching of scientific knowledge to be partially or even totally ignored, or also coated with a sense of a set of curiosities.

But the sense of teaching aimed at cultivating the qualities necessary for scientific discipline could still be found in the definitions aimed at the teaching of sciences in school groups, school types associated with urban life. The reports that school inspectors produced in those years show the expectation that this was also a purpose linked to the teaching of the subject in these establishments. An expectation that can also be detected in the reports that the graduates of the Normal Course, practitioners at the Model School, produced. The practitioner Levy Saldanha emphasized in one of his reports that scientific teaching in school groups should understand the "preliminary notions of Chemistry, Physics and Natural History, in order to cover everything that in their minds children could not ignore in order to keep away "superstition from their spirits" (DEAP, 1919, p. 96). Another practicing student in the Model Group recorded in her report, at the end of the following year, that the main objective of science lessons was to make children develop a sense of meticulous observation of objects, so that they could learn to deduce knowledge about all of the things that surrounded them from this appropriate sense of thorough observation (DEAP, 1920, p. 159).

This type of manifestation was still possible because it stemmed from the dialogue with another curricular configuration, the one that remained in effect only for school groups. And it is not simply because the program for school groups was broader than that prescribed for isolated schools, but because it was a program that contained other educational expectations.

Chart 2 - Program for the Study of Physical and Natural Sciences for the State's School Groups in 1921.

\begin{tabular}{|l|l|}
\hline \multirow{4}{*}{$\mathbf{1}^{\text {st }}$ Year } & A) Knowledge and distinction of colors. \\
& B) Observation of the external features of several bodies, their qualities \\
and uses. & C) Studies of known animals and their classification by external \\
features: feather, fur and scales animals; animals that walk, that fly, \\
that swim, that crawl; useful animals, harmful animals. \\
D) Knowledge of some animal products: meat, bone, leather, horn,
\end{tabular}




\begin{tabular}{|c|c|}
\hline & $\begin{array}{l}\text { teeth, feathers, fur, etc. } \\
\text { E) Lectures on known vegetables: utility and use of their products in } \\
\text { food, home remedies, construction and manufacturing of furniture, } \\
\text { fabrics, paper, etc. } \\
\text { F) Fruit trees from fields, jungles and orchards. } \\
\text { G) Advice on diet. } \\
\text { H) Advice on personal grooming. } \\
\text { I) Harmful effects of smoking and drinking alcohol. }\end{array}$ \\
\hline $2^{\text {nd }}$ Year & $\begin{array}{l}\text { A) Objective teaching of the states and qualities of the bodies; solid, } \\
\text { liquid and gaseous bodies; rough, smooth and slippery bodies; fragile, } \\
\text { resistant, porous, translucent, opaque, elastic, flexible bodies; } \\
\text { combustible, flammable, explosive, fusible, soluble, fibrous, granular, } \\
\text { sounding, astringent, spicy, acidic, sweet, salty bodies. } \\
\text { B) First observations on vertebrate and invertebrate animals; animals } \\
\text { that are useful and harmful to agriculture. Domestic animals. Animals } \\
\text { useful to men; harmful animals: means of defense that we have. } \\
\text { Studies of the life of some very important animals, such as ox, horse, } \\
\text { sheep, goat, domestic birds, bees, silkworm, etc. } \\
\text { C) Elementary study of the human body; general observations of the } \\
\text { human body; general observations on the hygiene of eating and of the } \\
\text { senses. } \\
\text { D) Care with the organ of sight to prevent the diseases that attack it. } \\
\text { E) Study of some useful produce: yerba mate, coffee, cotton, wheat, rice, } \\
\text { beans, potato, vegetables, etc. } \\
\text { F) Observations on seed germination. }\end{array}$ \\
\hline $3^{\text {rd Year }}$ & $\begin{array}{l}\text { A) Atmospheric air: barometers. } \\
\text { B) Air composition. Stale air. Air humidity and its causes. } \\
\text { C) Evaporation; observation on the general phenomenon of evaporation, } \\
\text { its causes and effects. } \\
\text { D) Rain: formation of rain and its effects. } \\
\text { F) Winds; its causes and its effects. } \\
\text { G) Very simple studies of some well-known minerals: iron, stone coal, } \\
\text { lead, copper, nickel, silver, gold. } \\
\text { H) Water; its composition. Fresh and saline waters. Brackish and } \\
\text { drinking waters. Mineral and medicinal waters. Thermal waters. } \\
\text { I) Heat; heat sources. Thermometers. } \\
\text { J) Animals; main characteristics of vertebrates and invertebrates. } \\
\text { K) Useful animals. } \\
\text { L) Man; main parts of the human body. Main skeleton bones. } \\
\text { M) Digestive system; its function. } \\
\text { N) Description of the instruments most used in agriculture. } \\
\text { O) The various processes for artificial reproduction of vegetables; } \\
\text { cutting, layering and grafting. } \\
\text { P) Growing of some useful vegetables in experience fields: coffee, cotton, } \\
\text { sugar cane, cereals. Fruit trees, leguminous plants. Benefits that } \\
\text { these plants provide to man. } \\
\text { Q) The growing of roses, carnations and other flowers. }\end{array}$ \\
\hline $4^{\text {th }}$ Year & $\begin{array}{l}\text { A) Brief explanations about the electric bell, telephone, telegraph, } \\
\text { lightning rod, pendulum, clock, electric light and power, air } \\
\text { circulation, air heating, gas lighting, the vapor pressure of water, the } \\
\text { corrosive action of acids and alkalis; the dissolving power of alcohol } \\
\text { and turpentine essence, etc.; steam and electricity applications, etc. } \\
\text { B) Animal classification: elementary study of the main classes of } \\
\text { vertebrates. } \\
\text { C) Elementary study of the human skeleton. }\end{array}$ \\
\hline
\end{tabular}




\begin{tabular}{|l|l|}
\hline D) General characteristics of the invertebrates. \\
& E) Respiratory, circulatory and digestive systems. \\
F) Elementary study of the senses. \\
G) Planting and growing of fruit trees and more useful vegetables typical \\
of our climate. Planting season and growing processes. Pruning \\
process season. \\
H) Fertilizers. \\
I) Hygiene of houses, clothes and food. Physical exercises, the need for \\
them, and their benefits. Rest and sleep. \\
J) Insects that transmit diseases. \\
K) Contagious and infectious diseases; malaria, tuberculosis, trachoma, \\
leprosy; means for preventing them, and how to treat them. \\
L) Antiophidic, anti-diphtheria and anti-tetanus serum; rabies and its \\
Mreventive treatment. \\
M) Vaccination against smallpox and typhoid fever. \\
N) Urgent care in case of injuries, fractures, vertigo, burns and asphyxia. \\
O) Care with injuries to the feet and hands; use of hydrophilic cotton, \\
gauze, bandages, iodine, hydrogen peroxide, etc.
\end{tabular}

Source: PARANÁ (1921, n.p.).

It is perceptible that, though present, the notion of utility is significantly less pronounced than in the program defined for isolated schools. In the program for school groups, the sense of utility seems more diffuse, less delimited and less specific. In addition, the accent to the procedural dimension is still quite pronounced - the cultivation of observation skills and experimental qualities as an educational value in itself -, especially in the initial part of the program. Finally, the presence of an encyclopedic sense is noticed, with a view to ensuring the student who completes the course with the apprehension of the statements and fundamental categories produced in the realm of the sciences, so that they can read and understand the world around them, be it this world created by human work or not. Reading and understanding the world in its various dimensions: the elements of nature, the functioning of the human body, the growing of different plants, the telephone, the telegraph and the electrical forces... therefore, also, but not only, from an occupational perspective. 


\section{FURTHER CONSIDERATIONS: ON EDUCATIONAL EXPECTATIONS FOR PRIMARY SCHOOL AND CURRICULAR HIERARCHIES}

The subject Physical and Natural Sciences was only officially established, in a continuous and permanent manner, in the program for the primary school of Paraná from the beginning of the 1910s, although this had been insinuated before so, in the second half of the 190os, in failed attempts at reforming schooling in Paraná. It is a relatively late appearance compared to other national realities, in which this corpus of knowledge was already provisioned in the programs for primary schools since the end of the XIX century (SOUZA, 2008).

As it has been characterized, the justifications for its inclusion in this initial moment were transformed and, to a great extent, differed from the claims for the continuity of its teaching and that prevailed throughout the 1920s. Along with the legitimizing rhetoric, the content listed in the programs was transformed as well. These movements make it possible to ascertain a dynamic of permanences and transformations internal to the subject in the space-time ambience of the early decades of the XX century in the context of Paraná. They are, in this sense, a localized contribution, the results of which must be crossed with the dynamics that took place elsewhere to produce a history that, from the point of view of school subjects, allows a more comprehensive understanding of the place and the meaning that was built for science teaching in primaryeducation systems in Brazil. Nevertheless, the history of science teaching outlined above helps understand important aspects regarding primary school in Paraná, about which some relevant points are worth noting.

It seems clear that the reasons listed for the inclusion of science teaching in the early XX century were gradually abandoned or transformed, to varying degrees, while their permanence in teaching programs were consolidating. The reasons for this to happen are connected with the way in which the subject was articulated with broader expectations for the primary 
school.

The arguments in favor of education as cultivation of the attitudes necessary for the development of the scientific spirit that were mobilized at the beginning of the $\mathrm{XX}$ century were related to the debate undertaken by intellectuals interested in promoting a tradition of agricultural studies in the primary-school curriculum ${ }^{11}$. In its general outlines, this debate addressed the (re)organization of the school articulated with a project of organization and development of Paranás society. Evoking the mesological and demographic characteristics of the state, the school should act to enhance in the population an agricultural vocation with a view to building from it a process of economic and social modernization, based on the fixation of man to the soil and on the enhancement of his productive forces. In arguments that at times compose with, at times propose alternative ways, but, in any case, nuance the modernizing expectations enclosed in the urban and industrial experience, in what was captured as his terrifying face: his vocation for the production of agglomerations of large impoverished population contingents and consequently, popular unrest and social disorder; moral and physical degeneration; precarious housing and hygiene; withered work capacities and individual initiative.

The breadth of the program was the focal point. All different stances were aimed at the tradition of the first-letters school and its insufficiency as an expression of popular education. The defense of scientific teaching is mobilized

\footnotetext{
${ }^{11}$ As an expression of that, Victor F. do Amaral and Dario Vellozo themselves can be mentioned, for their role in the debate and in the educational reform initiatives throughout the 190os. The former, a man of science (graduated from the Faculty of Medicine of Rio de Janeiro and an active name in the organization of the University of Paraná in the 1910s), came from the agrarian elites of the state. Still in the 1890 , he founded the Agricultural Society of Paraná. As a Congressman in the following decade, he defended - inspired by the North American experience of agricultural colleges - and presented bills for the creation of a federal agronomic institute and the funding of similar institutes in each unit of the federation. Part of the material on his parliamentary work in favor of agricultural education was gathered in the publication "Speeches and bills on agricultural education in the House of Representatives" [Discursos e projetos sobre educação agrícola na Câmara dos Deputados] (SILVA, 1907). Dario Vellozo, on the other hand, argued in favor of a process of repopulating the territory of Paraná in a balanced manner, formed by small population centers and based on polyculture capable of acting as a decentralizing force -, which should be related to an educational project that brought together liberal (humanistic) and practical (arts and crafts) traditions capable of promoting love for the land, for work and for life in the countryside.
} 
in this effort to develop a teaching program for the primary school that would make it possible to go beyond elementary knowledge, but that, in dialogue with other school traditions - such as the encyclopedic one, in addition to those associated with other levels of teaching, such as scientific, humanistic, polytechnic traditions - could broaden instruction beyond reading, writing and counting.

Two main stances that composed the common fund of this debate can be identified. The idea of a preliminary school mobilized around the work of Victor F. do Amaral; and the idea of a single or integral school, carried out mainly through the intellectual leadership of Dario Vellozo. It is, in fact, the perspectives that gain prominence in the reforms of 1907 and 1909, respectively.

The prospect of a preliminary school, as defended by Victor F. do Amaral, markedly present in the 1907 program, intends to be the common school, capable of integrating all possible educational trajectories - considering the diversity of social existences present in the reality of Paraná - and relate them to the subsequent educational steps. This understanding leads to the proposal of a five-year program based on a strict teaching grading, divided into two grades. In the first grade, comprising the first four years, the program should cover, in the first one, the core of the first-letters school (that is, only the subjects Reading, Calligraphy and Arithmetic), to progressively expand in the following years. Not only because, as the student advanced in the course, they should gradually deepen the study of the subjects, but also because each year new subjects should be added until reaching the fourth year with the following array: Reading, Calligraphy, Arithmetic, Geography, Grammar, Homeland History, Linear Drawing and Agronomy. This way, the school would be able to adjust itself to the reality of those populations that could not have more than one or two years of attendance and that expected no more than learning to read, write and count; including those who, staying in school longer, had a terminative character at the level of primary education and who would dedicate 
themselves to the diversity of occupations; also reaching those who would access other educational stages, such as professional training courses or secondary education. The second grade, lasting only one year (in which French and Physical and Natural Sciences were included), should serve as a stage to link primary and secondary education. According to the proposal, it would be dispensable for all students who resorted to some path of professional training teaching. For those seeking access to higher levels, it should replace the current practice of preparatory studies (PARANÁ, 1907).

The conception of the single or integral school defended by Vellozo, in its turn, was thought of as the stage or as a common instance of socialization of the population, regardless of the projected geographic, social and even occupational reality. A school for all, designed in dialogue with the renewing propositions and inspired by the assumptions of Ferrer i Guàrdia's Modern School and, mainly, of E. Demolins's New School. It should integrate scientific, humanistic or literary, artistic or aesthetic knowledge and the principle of work, through handwork workshops.

Whether from the perspective of comprehensive training with a view to human emancipation (of conscience), or from the perspective of erecting the lower floors of the educational building - which should be carried out in later studies or in the course itself of social and occupational existence -, scientific teaching would correspond to a fundamental learning to promote autonomy of conscience and individual initiative, condition and content of the image of the active individual, engine of moral and material progress. Only through the action of this individual of initiative it would be possible to carry on the civilizational impulse, whose main lines meant the guarantee of social peace mediated by the rule of law and of official institutions; the republican political activity, made equal to voting; and the transformation of customs and of the material conditions of existence, associated with the prosperity generated by labor and individual effort.

Looking at the complex formed by educational purposes and cultural 
content in relation to the presence of the subject Physical and Natural Sciences in the 1920s, we notice that a significant portion of those senses are disappearing or present in a restricted manner. The main absence seems to be the broader sense of scientific education, that is, the sense of investigative mentality associated with the disenchantment of the world and the spirit of autonomy and individual initiative.

The programs that came to light in the early 1920 s are important milestones in consolidating the sense that the presence of the primary school in the society of Paraná corresponds to a school of the elementary type. Such programs, in which science teaching is an element among others, can be interpreted as the point of arrival of a process that abandoned the intentions and assumptions that strained the elementary-school project and proposed the cultural and formative expansion for the primary school. It is significant that the 1907 and 1909 programs were quickly abandoned on the grounds that they were, incongruous and beyond the financial capacity of the state (the former), and "unenforceable" (the latter) (XAVIER, 1909; 1911).

These more general senses that arise from what can be characterized as a formative project for the primary school, more than framing the presence of the subject in the programs, help define the statute of this presence. First, the emphasis placed on expanding primary schooling in order to fight illiteracy in the population of Paraná enshrined in the programs the priority of learning writing, reading and calculus. Most of the population that studied at the primary school in the 1920 s did so by attending a program with a maximum length of three years. But the authorities had no problem recognizing that the vast majority dropped out of school and engaged in work activities at the end of the first or second year. This picture helped produce a hierarchy of knowledge that assigned the teaching of sciences with a sense of secondary, accessory or even eventual subject matters in many of the schools. The fact that the expansion of the primary school was due to policies for attracting and training teachers who did not take normal courses contributed to this. There is a significant number of 
reports, from inspectors and from the teachers themselves, indicating that the latter did not feel capable of or had difficulties in teaching science lessons.

The election of priorities related to the demarcation of the primary school as a mass school - which allowed enrollment at public primary schools to jump from something close to 8,000 in the mid-1900s to almost 60,000 near the end of the 1920s (Cf. MUNHOZ, 1926) - abandoned educational expectations, formative senses and cultural contents that were seriously defended at the beginning of the XX century. Several names involved in the debate in the early 1900 sustained that, as for the efforts of public authorities towards providing primary schooling, quality was more important than quantity. A premise that faded as the appeal for the literacy of the population and the moralization of customs began to take center stage in relation to the social and cultural expectations for the primary school.

The very semantic load of the notion of utility, which since the end of the XIX century was fundamental for the defense of scientific teaching, had been transformed in the association with science teaching in the 1920s. While those names that advocated for scientific teaching as the cultivation of a sensitivity mobilized the notion of utility in order to encompass other dimensions of human existence beyond the occupational one - such as breadth of thinking, capacity for action or initiative and aesthetic fruition -, within the framework of the programs of the 1920 s said notion is basically limited to the most immediate labor dimension (to work in the field, when it comes to schools located in the rural environment, or to factory work, when it comes to schools located in the urban and suburban environment), and the acquisition of hygiene habits. It is a redefinition that points to the restriction of the scope of the notion.

More visible traits of the perspective of scientific teaching as cultivation of a sensitivity can still be found in the programs targeting school groups. Although since the beginning of the 1920 s the authorities admitted that many school groups did not offer the entire primary course, especially in those that started to be built in less populous locations and that should also prioritize the 
fight against illiteracy, the fact is that some students who attended better structured school groups, especially those located in the main cities of the state, had access to a broader and more intense program and, consequently, to greater cultural opportunities in relation to contact with scientific content. This was made possible by the curriculum bipartition strategy implemented in the beginning of that decade. Based on the elements gathered from the reports of teachers, principals and school inspectors, it can be said that they have become small areas that offered a privileged school cultural experience that differed from the most frequent reality of schooling in Paraná, in which an emphasis on literacy and on transformation and moralization of customs predominated.

\section{REFERENCES}

BRAGHINI, Katya; MUNAKATA, Kazumi; TABORDA DE OLIVEIRA, Marcus A. (org.). Diálogos sobre a história da Educação dos sentidos e das sensibilidades. Curitiba: Editora UFPR, 2017.

CAMPOS, Névio de. Intelectuais católicos e a educação no Paraná nas décadas de 1920 e 1930. In: VIEIRA, Carlos E. (org). Intelectuais, Educação e Modernidade no Paraná (1886 - 1964). Curitiba: Ed. UFPR, 2007.

DEAP/PR. Relatório do praticante Levy Saldanha. In: Coleção

Correspondência do Governo: v. 9; AP 1739, 1919, p. 91 - 109.

DEAP/PR. Relatório da praticante do Grupo Escolar Modelo, Emilia Vianna. In: Coleção Correspondência do Governo: v. 25; AP 1756, 1920p. 156 - 162.

GOODSON, Ivor. Currículo: Teoria e História. Trad. Atillio Brunetta. Petrópolis, RJ: Vozes, 1995.

PARANÁ, Estado do. Regulamento da Instrucção Publica do Estado do Paraná. Curitiba: Typ. D’A Republica, 1907.

PARANÁ, Estado do. Regulamento Orgânico da Instrucção Pública do Estado do Paraná. Curitiba: Typ. D’A Republica, 1909.

PARANÁ, Estado do. Instruções Sobre Organização Escolar e Programma de Ensino para as Escolas Públicas do Estado do Paraná. 
Curitiba: Diretoria Geral da Instrução Pública, 1914.

PARANÁ, Estado do. Programa do Grupo Escolar Modelo e Similares. Curitiba: Typ. d'A Republica, 1917.

PARANÁ, Estado do. Programma das escolas isoladas, com instrucções da Inspectoria Geral do Ensino. Curitiba: Inspectoria Geral do Ensino, 1920.

PARANÁ, Estado do. Programma dos Grupos Escolares do Estado do Paraná. Curitiba: Irmãos Guimaraes \& Cia, 1921.

MARTINEZ, Cesar Prieto. Relatório apresentado pelo Inspetor Geral do Ensino. Curitiba: Typ. da Penitenciaria do Estado, 1920.

MARTINEZ, Cesar Prieto. Relatório apresentado pelo Inspetor Geral do Ensino. Curitiba: Typ. da Penitenciaria do Estado, 1921.

MARTINEZ, Cesar Prieto. Relatório apresentado pelo Inspetor Geral do Ensino. Curitiba: Typ. da Penitenciaria do Estado, 1922.

MARTINEZ, Cesar Prieto. Relatório apresentado pelo Inspetor Geral do Ensino. Curitiba: Typ. da Penitenciaria do Estado, 1923.

MORENO, Jean Carlos. Intelectuais na década de 1920: César Prieto Martinez e Lysimaco Ferreira da Costa à frente da instrução pública do Paraná. In: VIEIRA, Carlos E. (org). Intelectuais, Educação e Modernidade no Paraná (1886 - 1964). Curitiba: Ed. UFPR, 2007.

MOREU, Alicia. A pedagogia e a Eschola. In: A Escola, Ano I, n. 10 e 11, p. 156 $-162,1906$.

MUNAKATA, Kazumi. Que coisa é coisa das lições de coisas? In: TABORDA DE OLIVEIRA, Marcus. A. (org.). Sentidos e sensibilidades: sua educação na história. Curitiba: UFPR, 2012.

MUNHOZ, Alcides. Relatório da Secretaria Geral do Estado do Paraná. Curitiba: Livraria Mundial, França \& Cia. 1926.

SACRISTÁN, José Gimeno. O currículo: uma reflexão sobre a prática. Porto Alegre: Artmed, 2000.

SANTOS, Claudino Rogoberto Ferreira. Relatório da Secretaria dos Negócios do Interior, Justiça e Instrução Pública - 1913. Curitiba: Typ. do Diario Oficial, 1914. 
SANTOS, Claudino Rogoberto Ferreira. Relatório da Secretaria dos Negócios do Interior, Justiça e Instrução Pública - 1914. Curitiba: Typ. do Diario Oficial, 1915.

SILVA, Octavio Ferreira do Amaral. Relatório da Secretaria dos Negócios do Interior, Justiça e Instrução Pública e Anexos (1903). Curitiba: Typ. da Republica, 1904.

SILVA, Victor Ferreira do Amaral. Discursos e projetos sobre educação agrícola na Câmara dos Deputados. Curitiba: Typographia da Republica, 1907.

SOUZA, Rosa Fátima de. História da organização do trabalho escolar e do currículo no século XX: (ensino primário e secundário no Brasil). São Paulo: Cortez, 2008.

VALDEMARIN, Vera Tereza. Os sentidos e a experiência. Professores, alunos e métodos de ensino". In: SAVIANI, D. [et al]. O legado educacional do século XX no Brasil. Campinas: Autores Associados, 2004.

VELLOZO, Dario. Subsídios Pedagógicos. In: A Escola. Ano II, n. 1 - 4, p. 1 $5,1907$.

VELLOZO, Dario. Subsídios Pedagógicos da Instrução Popular Hodierna. In: A Escola, Ano IV, n. 2 - 3, p. $44-62,1909$.

VIEIRA, Carlos Eduardo. O movimento pela Escola Nova no Paraná: trajetória e ideias educativas de Erasmo Pilotto. In: Educar em Revista, v. 17, n. 18, p. 53 $-73,2001$.

XAVIER, Luiz Antonio. Relatorio do Secretario d'Estado dos Negocios do Interior, Justiça e Instrucção Publica - 1908. Curitiba: Typ. D'A Republica, 1909.

XAVIER, Luiz Antonio. Relatorio do Secretario d'Estado dos Negocios do Interior, Justiça e Instrucção Publica - 1910. Curitiba: Typ. D’A Republica, 1911. 
SIDMAR DOS SANTOS MEURER é Professor Adjunto na Universidade Federal do Paraná (UFPR), Setor de Educação, e no Programa de PósGraduação em Educação - UFPR. É Licenciado em Educação Física pela Universidade Federal do Paraná (2005) e Mestre em Educação, também pela UFPR (2008), e Doutor em Educação: Conhecimento e Inclusão Social (2019), pela Universidade Federal de Minas Gerais. Está vinculado ao Núcleo de Pesquisas sobre a Educação dos Sentidos e das Sensibilidades (NUPES) - UFMG, e ao Grupo de Pesquisa: História da Educação: instituições, intelectuais e culturas escolares no Paraná (séculos XIX - XX), na UFPR.

E-mail: sid_meurer@ufpr.br

(1) http://orcid.org/0000-0001-6394-4859

Recebido em: 24 de abril de 2020

Aprovado em: 26 de janeiro de 2021

Editora responsável: Terciane Luchese 